\title{
ANTIMICROBIAL ACTIVITY AND PHYTOCHEMICAL SCREENING OF THE LEAF EXTRACTS OF EUCALYPTUS GLOBULUS
}

\author{
SUBRAMANIAN ABIRAMI, KANNAN NISHANTHINI, MANI POONKOTHAI* \\ Department of Zoology, Avinashilingam Institute for Home Science and Higher Education for Women, Coimbatore 641043, Tamil Nadu, India \\ Email: poonkothaiadu@gmail.com
}

Received: 20 May 2017, Revised and Accepted: 22 Jul 2017

\section{ABSTRACT}

Objective: To investigate the antimicrobial activity and phytochemical analysis of Eucalyptus globulus leaves.

Methods: The antimicrobial activity of the leaves of E. globulus extracted with acetone, ethanol and petroleum ether was studied using well diffusion method against the selected bacterial and fungal isolates. The antimicrobial susceptibility of the bacteria and fungi to various concentrations of the extract was evaluated by the micro broth dilution method. The preliminary phytochemical screening was performed in the acetone extract of E. globulus. The presence of functional groups in the acetone extract of the leaves of E. globulus was determined by Fourier to transform infrared (FT-IR) spectroscopy.

Results: Results suggested that the acetone extract exhibited maximum antimicrobial activity against the tested bacteria and fungi when compared with ciprofloxacin and fluconazole respectively (standard antibiotics). Minimum inhibitory concentration (MIC) showed that the wells containing a concentration of $12.5 \mathrm{mg} / \mathrm{ml}$ and $6.25 \mathrm{mg} / \mathrm{ml}$ of acetone extract inhibited the bacteria and fungi effectively. Phytochemical screening of acetone extract of E. globulus showed the presence of alkaloids, flavonoids, phenols, tannins, quinones, glycosides, steroids, terpenoids and leucoanthocyanides. FT-IR spectral analysis of the leaf extract of E. globulus showed the presence of functional groups such as- $\mathrm{OH}$,- $\mathrm{NH}$, C=0 and$\mathrm{COOH}$.

Conclusion: Thus to conclude, different plants and their formulations have been used in ayurveda to cure diseases for several decades. The findings of the study indicate the potential to exploit the leaves of Eucalyptus globulus in the treatment of microbial diseases.

Keywords: Eucalyptus globulus, Phytochemical analysis, Antimicrobial activity, Microbroth dilution method, FT-IR spectroscopy

(C) 2017 The Authors. Published by Innovare Academic Sciences Pvt Ltd. This is an open access article under the CC BY license (http://creativecommons.org/licenses/by/4.0/) DOI: http://dx.doi.org/10.22159/ijcpr.2017v9i5.22145

\section{INTRODUCTION}

Medicinal plants a boon to human beings contain a wide range of bioactive compounds or phytochemicals which are used to treat various ailments [1-3]. They are used worldwide in folk medicine and screening of such plants may result in the discovery of novel effective compounds against pathogenic microbes. Now-a-days miscellaneous usage of synthetic drug leads to countless side effects and this converges an idea to use medicinal plants as an alternative [4]. The plant based technique of medicine being natural does not cause any serious side effects or problems [5]. Almost all parts of plants are used to treat various diseases which are known to have diverse medicinal properties [6].

During last three decades, numerous antibiotics have been produced, but the clinical efficiency of these existing antibiotics is being threatened by the emergence of multidrug resistant pathogens [7]. According to World Health Organization (WHO), it was reported that medicinal plants would be the best source to obtain a variety of drugs [8]. Antibiotic resistance has become a global concern in recent decades and there is a growing concern regarding the search for new antimicrobial substances from different sources of medicinal plants [9]. The screening of plant extracts and plant products for antimicrobial activity has shown that higher plants represent a potential source of novel antibiotic prototypes [10].

Eucalyptusglobulus, an important medicinal plant of Mrytaceae are used in many parts of the world for the treatment of a wide variety of diseases. It acts as an antiseptic agent, and the leaf extracts are used to treat influenza, skin rashes, chest problems and their vapour is inhaled to fight inflammation. It stimulates the release of saliva and helps loosen a cough and used to treat lung infections and gastro intestinal ulcers. E. globulus oil has useful antipyretic properties to reduce fever and decreases blood sugar level. $E$. globulus-also contains many aromatic principles which find out its existence in the composition of many products such as shampoos, toothpaste, soaps, ointments, air fresheners etc. [11].

Thus the present study is sought to evaluate the in-vitro antimicrobial activity and phytochemical analysis of Eucalyptusglobulus.

\section{MATERIALS AND METHODS}

\section{Plant material}

The leaves of E. globules Labill were collected during June 2016 from Kariyamandu, Ooty, Nilgiris district with the help of tribal people dominating that area. The leaves were air-dried in shade at ambient temperature and stored in double layer paper bags at room temperature, powdered and protected from the direct light, until further analysis. The plant specimen was identified at the Department of Botany, Avinashilingam University for Women, Coimbatore, Tamilnadu, India.

\section{Extract preparation}

The leaf extracts were prepared using the solvents namely acetone, petroleum ether and ethanol. The dry leaf sample (10g) was weighed and homogenized with $100 \mathrm{ml}$ of the respective solvents separately. The crude preparation was left over night in the shaker at room temperature. The leaf extract was then transferred to a pre weighed beaker and the extract was concentrated by evaporating the solvent at $60{ }^{\circ} \mathrm{C}$. The crude extract was weighed and dissolved in a known volume of dimethyl sulphoxide. The extraction yield was expressed as.

$$
\text { Extraction yield }(\%)=\frac{\text { Weight of the dry extract }(\mathrm{g})}{\text { Weight of the sample used for the extraction }(\mathrm{g})} \times 100
$$

\section{Antimicrobial screening}

In order to evaluate the antimicrobial activity of E. globulus, the bacterial strains used for the present study are Escherichia coli, 
Klebsiellapneumoniae, Pseudomonas aeruginosa, Shigellaflexneri, Vibrio cholera, Streptococcus epidermis, Bacillus cereus, Staphylococcus aureus and Proteus vulgaris. The fungal strains used were Aspergillus niger, Aspergillusflavus, Aspergillusfumigatus, Penicillum species, Trichoderma species and Rhizopus species.

The agar well diffusion method was employed to determine the antimicrobial activity of the leaf extracts of E. globulus. Briefly, the above-mentioned bacteria were cultured on the nutrient broth (Himedia, Mumbai, India) at $37 \pm 0.1^{\circ} \mathrm{C}$ while the fungi were grown on Sabauroud dextrose broth (Himedia, Mumbai, India) at $28 \pm 0.1^{\circ} \mathrm{C}$. The well grown bacterial and fungal cultures $(100 \mu \mathrm{l})$ were spread plated/swabbed on sterile Muller Hinton and Sabauroud dextrose agar media separately. Five wells were made on each plate and to each well $20 \mu \mathrm{l}$ of the leaf extracts, ciproflaxin (bacteria) and flucanozole (fungi) which served as positive control/reference antibiotics and DMSO (negative control) were added and incubated at $37^{\circ} \mathrm{C}$ for $24 \mathrm{~h}$ (bacteria) and at room temperature for $5 \mathrm{~d}$ (fungi) respectively. After the incubation period, the diameter of the inhibition zones was measured.

\section{Microbroth dilution assay}

The antimicrobial susceptibility of the bacteria and fungi to various concentrations of the extract was evaluated by the micro broth dilution method [12]. The bacterial and fungal cultures were grown in sterile nutrient broth and Sabouraud dextrose broth separately. A volume of $99 \mu \mathrm{l}$ of the medium with respective microbes was added to the wells of microtitre plates separately. The concentration of the plant extract was $100 \mathrm{mg} / \mathrm{ml}$. The different concentrations of the extract were prepared and then the wells were inoculated with $1 \mu \mathrm{l}$ of the selected extracts separately. The plates were incubated at $37^{\circ} \mathrm{C}$ for $24 \mathrm{~h}$ (bacteria) and at room temperature for $5 \mathrm{~d}$ (fungi) respectively. The activity was observed as negative if growth was there and positive if the medium appeared clear without any growth of the microbes and the minimum inhibitory concentration was noted.

\section{Phytochemical analysis}

The acetone extract of E. globules leaf was subjected to preliminary phytochemical tests namely carbohydrates, amino acids, phenols, steroids, glycosides, quinones, alkaloids, tannins, anthocyanin, volatile oils, terpenoids, coumarins and leucoanthocyanides as per the standard methods [13].

\section{FT-IR analysis}

The powdered acetone extract of E. globules $(1 \mu \mathrm{g})$ leaves we remixed with $2.5 \mathrm{mg}$ of dry potassium bromide and grounded wellusing mortar and pestle. The powder was filled in a $2 \mathrm{~mm}$ internal diameter micro-cup and loaded onto FT-IR spectrophotometer at $26^{\circ} \mathrm{C} \pm 1^{\circ} \mathrm{C}$. The samples were scanned using infrared rays in the range of $4000-750 \mathrm{~cm}^{-1}$ by Fourier Transform Infrared Spectrophotometer. The spectral data were compared with the reference chart to identify the functional groups responsible for biological activities in the sample [14].

\section{RESULTS}

It was observed that acetone extraction produced the maximum yield of $28.1 \%$, whereas in ethanol extraction the yield was $17.5 \%$ and petroleum ether extraction yielded only $10.2 \%$. The results of the antimicrobial activity were summarized in table 1 . E. globulus leaf extracts showed potent antimicrobial activity in acetone extract when compared with ethanol and petroleum ether extract. The acetone extract of E. globules exhibited a maximum zone of inhibition against Streptococcus epidermis $(27 \mathrm{~mm})$ followed by E. coli $(26 \mathrm{~mm})$ and minimum zone of inhibition was noticed in Shigellaflexneri $(17 \mathrm{~mm})$. Similarly, the Gram positive bacteria Bacillus cereus and Staphylococcus aureus exhibited of the zone of inhibition of $24 \mathrm{~mm}$ against acetone extract. Followed by acetone extract, ethanol extract exhibited moderate activity and petroleum ether extract of $E$. globulus revealed minimum activity (table 1) when compared with the standard antibiotic, ciprofloxacin (19-28 $\mathrm{mm})$ which served as positive control.

Table 1: Antibacterial activity of the leaf extracts of E. globulus

\begin{tabular}{|c|c|c|c|c|c|}
\hline \multirow[t]{2}{*}{ Bacterial isolates } & \multicolumn{5}{|c|}{ Zone of inhibition in diameter (mm) } \\
\hline & ACE & ETH & $\mathbf{P E}$ & CPF & DMSO \\
\hline Streptococcus epidermis & 27 & 25 & 21 & 28 & - \\
\hline Vibrio cholera & 23 & 15 & 12 & 24 & - \\
\hline Pseudomonas aeruginosa & 25 & 17 & 15 & 27 & - \\
\hline Shigellaflexneri & 17 & 14 & 9 & 19 & - \\
\hline Escherichia coli & 26 & 23 & 20 & 27 & - \\
\hline Proteus vulgaris & 19 & 15 & 10 & 20 & - \\
\hline Klebsiella pneumoniae & 22 & 18 & 13 & 25 & - \\
\hline Bacillus cereus & 24 & 20 & 14 & 26 & - \\
\hline Staphylococcus aureus & 24 & 20 & 13 & 26 & - \\
\hline
\end{tabular}

ACE-Acetone Extract ETH-Ethanol Extract PE-Petroleum Ether Extract, CPF -Ciproflaxin (Positive control) DMSO-Dimethyl Sulphoxide (Negative control)

The inhibitory activity of $E$. globulus leaf extract against the tested fungal isolates was depicted in table 2. Acetone extract of $E$. globulus leaf exhibited a maximum zone of inhibition against Rhizopusstolonifer (23 $\mathrm{mm})$ followed by Aspergillus niger $(22 \mathrm{~mm})$ and minimum zone of inhibition was noticed in Aspergillusflavus $(10 \mathrm{~mm})$. Petroleum ether extract of E. globulus possessed minimum activity and moderate zone of inhibition was observed in ethanol extract against the tested fungal isolates when compared with fluconazole (standard antibiotic/positive control) which produced the inhibition zone of $13-25 \mathrm{~mm}$. The negative control (DMSO) showed no zone of inhibition against the tested bacterial and fungal isolates.

Table 2: Antifungal activity of the leaf extracts ofE. globulus

\begin{tabular}{llllll}
\hline \multirow{2}{*}{ Fungal isolates } & \multicolumn{2}{l}{ Zone of inhibition in diameter (mm) } & & DMSO \\
\cline { 2 - 6 } & ACE & ETH & PE & FLU & - \\
\hline Aspergillus niger & 22 & 18 & 16 & 23 & - \\
Penicillium species & 17 & 13 & 11 & 18 & - \\
Aspergillus fumigatus & 16 & 14 & 13 & 17 & - \\
Rhizopusstolonifer & 23 & 20 & 17 & 25 & - \\
Aspergillusflavus & 10 & 9 & 8 & 13 & - \\
Trichoderma species & 20 & 15 & 10 & 21 & \\
\hline
\end{tabular}

ACE-Acetone Extract ETH-Ethanol Extract PE-Petroleum Ether Extract FLU-Flucanozole (Positive control) DMSO-Dimethyl Sulphoxide (Negative control) 
The screening for minimum inhibitory concentration (MIC) showed that the wells containing a concentration of $12.5 \mathrm{mg} / \mathrm{ml}$ and $6.25 \mathrm{mg} / \mathrm{ml}$ of acetone extract inhibited the bacteria and fungi respectively, followed by ethanolic extract $(25 \mathrm{mg} / \mathrm{ml})$ and petroleum ether extract $(50 \mathrm{mg} / \mathrm{ml})$.
The phytochemical analysis in the acetone extract of E. globulus leaves showed the presence of phytoconstituents such as alkaloids, flavonoids, phenols, tannins, quinones, glycosides, steroids, terpenoids, volatile acids and leucoanthocyanides (table 3).

Table 3: Phytochemical analysis of E. globulus

\begin{tabular}{|c|c|c|}
\hline S. No. & Phytochemicals & Acetone extract \\
\hline \multirow[t]{3}{*}{1} & Alkaloids & \\
\hline & Dragendroff's reagent & - \\
\hline & Wagner's reagent & + \\
\hline 2 & Flavonoids & + \\
\hline \multirow[t]{3}{*}{3} & Phenols & \\
\hline & Ferric chloride test & + \\
\hline & Lead acetate test & - \\
\hline \multirow[t]{3}{*}{4} & Amino Acids & \\
\hline & Ninhydrin test & - \\
\hline & Biuret test & - \\
\hline \multirow[t]{2}{*}{5} & Tannins & \\
\hline & Lead acetate test & + \\
\hline \multirow[t]{2}{*}{6} & Quinones & \\
\hline & Sodium hydroxide test & + \\
\hline \multirow[t]{2}{*}{7} & Carbohydrates & \\
\hline & Fehling's test & - \\
\hline \multirow[t]{2}{*}{8} & Glycosides & \\
\hline & Legal's test & + \\
\hline \multirow[t]{2}{*}{9} & Steroids & \\
\hline & Salkowski test & + \\
\hline \multirow[t]{2}{*}{10} & Starch & \\
\hline & Iodine test & - \\
\hline 11 & Antocyanin & - \\
\hline 12 & Volatile Oils & + \\
\hline 13 & Terpenoids & + \\
\hline 14 & Coumarins & - \\
\hline 15 & Leucoanthocynidines & + \\
\hline
\end{tabular}

FT-IR spectral analysis of acetone extract of E. globulus leaf revealed the presence of different functional groups (fig. 1). Spectral data of the extract confirmed the presence of functional groups such as- $\mathrm{OH}$, $\mathrm{NH}, \mathrm{C}=\mathrm{O}$ and $-\mathrm{COOH}$. The peak at $3441.01 \mathrm{~cm}^{-1}$ was assigned to the $\mathrm{O}-\mathrm{H}$ stretching vibration, the peak appeared in the range of 1165 $879.54 \mathrm{~cm}^{-1}$ is mainly attributed to the stretching vibration of C-O. The characters of peak intensities and position at 3332.99 and
$3248.13 \mathrm{~cm}^{-1}$ in the IR spectrum display the characteristic absorption of $\mathrm{H}$ bonded $\mathrm{OH}$ stretching. The hydroxyl peak at $3379.29 \mathrm{~cm}^{-1}$ and the peak situated at $1705.07 \mathrm{~cm}^{-1}$ was assigned to the absorption of carbonyl $(-\mathrm{C}=0$ stretching). Peaks in the range between $3650-3300 \mathrm{~cm}^{-1}$ correspond to stretching vibrations of $\mathrm{OH}$ groups as well as from amides. The peak at 2916.37, 2854.65, 2800.64 and $2754.35 \mathrm{~cm}^{-1}$ belongs to the $\mathrm{C}-\mathrm{H}$ stretching vibrations.

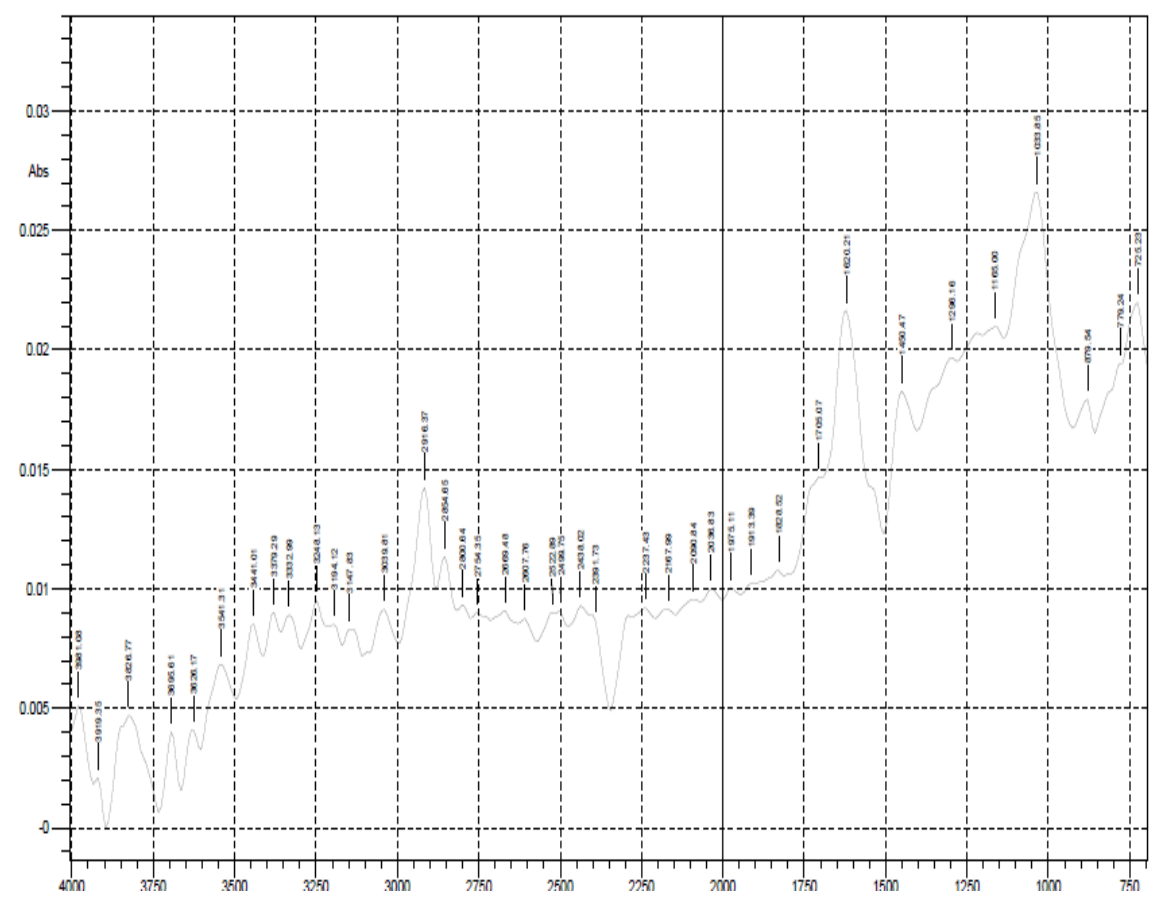

Fig. 1: FT-IR spectrum of the leaf extract of E. globules 


\section{DISCUSSION}

Medicinal plants serve to be a source of remedy for many diseases and place an important role in the health of an individual and society. E. globulus leaf extracts possessed a significant antimicrobial activity against the tested bacterial and fungal isolates. Among the tested extracts acetone proved to possess strong antimicrobial activity which suggests that it is a dipolar aprotic solvent of medicinal polarity and can dissolve a wide range of compounds [15].

Additionally, acetone possesses extra carbon than ethanol which aids in the extraction of other compounds and this may be the reason for better antimicrobial activity in acetone extract when compared with ethanol and petroleum ether extracts. E. globulus seems to be a potential remediant for the treatment of many infectious diseases and also be used as natural food preservative [16-18]. The inhibitory effect of the leaf extract of the candidate plant will be helpful to pharmacological industry to prepare antimicrobial drugs for treating various bacterial and fungal diseases. Hence E. globulus proves to be a promising agent to cure various infections/diseases and has a wide spread use in the pharmacological system.

Presence of phytochemical constituents such as alkaloids, flavonoids, phenols, tannins, quinones, glycosides, steroids, terpenoids and leucoanthocyanidins served as a defence mechanism against microorganisms [19]. The presence of flavonoids, alkaloids, tannins, glycosides and terpenoids may disrupt the cell membrane of bacteria and forms a complex with extracellular soluble proteins and thereby inhibits its growth [20]. The flavonoids are more lipophilic and may also disrupt the microbial membranes. The presence of alkaloids may intercalate with the DNA of the microbes and fight against infectious diseases [21]. Similarly, the presence of steroids is known to have a cardio tonic effect and also possess antibacterial and insecticidal properties [22]. Tannins also precipitate the microbial proteins, thus making the nutritional proteins unavailable for microbial growth. In the same manner, the presence of polyphenols and secondary metabolites fight against the bacterial and fungal diseases [23]. Presence of cardiac glycosides may inhibit the $\mathrm{Na}^{+} / \mathrm{K}^{+}$pump and increases the availability of calcium ions for the contraction of heart muscles which reduces the congestive heart failure, cardiac arrhythmia and distension of heart $[24,25]$. The present work reveals the presence of various phytochemical constituents in the plant extract which provides a scientific validation for its use in folk medicine in the selected area which is renowned for tribal community. Further advanced research activities on the isolation of the compounds in the plant extract can be explored.

In any bio-organic molecule, its functional groups influence its biological activity considerably as they contribute significantly to their inherent acid-base properties, solubility, partition coefficient, crystal structure and stereochemistry and so on. All these properties are supposed to influence the absorption, distribution, metabolic extraction and toxicity of bioactive molecules [26]. In the present work, FT-IR spectral analysis of the leaf extract of E. globulus illustrated the presence of phytochemicals carrying hydrogen bonded- $\mathrm{OH},-\mathrm{NH}, \mathrm{C}=\mathrm{O}$ and $-\mathrm{COOH}$ functional groups. The hydroxyl functional group seems to be an integral part of phenolic phytochemicals and also the presence of various biologically active functional groups, viz. alcoholic, amide, carbonyl and carboxylic groups confirms that the plant possesses bioactive phytochemicals. Thus to conclude the results of the above study clearly demonstrate that the acetone extract of globules exhibits moderate antibacterial and antifungal activities which might be helpful in preventing the progress of various infectious diseases and can be used in the alternative system of medicine. The effective biomolecules which act as antimicrobial substance have to be isolated and identified so that it could become the base for the development of medicine for the drug resistant microorganisms and also a natural blueprint for the development of new drugs.

\section{ACKNOWLEDGMENT}

The authors thank the authorities of Avinashilingam Institute for Home Science and Higher Education for Women, Coimbatore, Tamil Nadu, India for providing facilities to carry out the research work.

\section{AUTHORS CONTRIBUTION}

Abirami and Nishanthini were involved in phytochemical and FT-IR spectral analyses of Eucalyptusglobulus leaf extract. Poonkothai contributed in antimicrobial activity of different extracts of Eucalyptusglobulus.

\section{CONFLICT OF INTERESTS}

The authors declare that they have no conflict of interest.

\section{REFERENCES}

1. Kiruba S, Mahesh M, Nisha SR, Miller Paul Z, Jeeva S Phytochemical analysis of the flower extracts of Rhododendron arboretum Sm. Ssp. Nilagiricum (Zenker) Tagg. Asian Pac J Trop Biomed 2011;S:284-6.

2. Rao TG, Babu SK, Kumar UJ, Sujana P, Rao V, Sreedhar AS. Antimicrobial principles of selected remedial plants from Southern India. Asian Pac J Trop Biomed 2011;1:298-305.

3. Raja ARD, Jeeva S, Prakash JW, Johnson M, Irudayaraj V. Antibacterial activity of selected ethanomedicinial plants from South India. Asian Pac J Trop Med 2011;4:375-8.

4. Nostro A, Gemano MP, Dangelo V, Marino A, Cannatelli MA. Extraction methods and bioautography for evaluation of medicinal plants antimicrobial activity. Lett Appl microbiol 2000;30:379-84

5. Ayyanar I. Herbal medicines of wound healing among tribal people in Southern India: Ethnobotanical and Scientific Evidences. Int J Appl Res Nat Prod 2009;2:29-42.

6. Chakraborthy A, Brantner AH. Antibacterial activity of the stem bark of Holarrhenapubescens (Syn. H. antidysenterica) J Ethnopharmacol 1999;68:339.

7. Bandow JE, Brotz H, Leichert LO. Proteomic approach to understanding antibiotic action. Antimicrob Agents Chemother 2003;47:948-55

8. Santos PRV, Oliveira ACX, Tomassini TCB. Control microbiogicodeproductos. Fitoterapicos. Rev Farm Bioquim 1995;31:35-8.

9. Westh H, Zinn CS, Rosdahl VT. Sarisa study group: an international multicenter study of antimicrobial consumption and resistance in Staphylococcus aureus. Microb Drug Resist 2004; 10:169-76.

10. Afloyan AJ. Extracts from the shoots of Arctotis arctotoides inhibit the growth of bacteria and fungi. Pharm Biol 2003;41:22-5.

11. Musyimi DM, Ogur JA. Comparative assessment of antifungal activity of extracts from Eucalyptusglobulusand Eucalyptuscitriodora. Res J Phytochem 2008;2:35-43.

12. Barchiesi F, Colombo AL, McGough DA, Fothergill AW, Rinaldi MG. In vitro activity of itraconazole against fluconazolesusceptible and resistant Candida albicans isolates from oral cavities of patients infected with human immunodeficiency virus. Antimicrob Agents Chemother 1994,38:1530-3.

13. Harborne JB. Phytochemical methods: a guide to modern technique of plant analysis. London: Chapman and Hall; 1973. p. 271.

14. Naumann D. Infrared spectroscopy in microbiology. Meyers RA. ed. Encyclopedia of Analytical Chemistry. John Wiley and Sons, Chichester UK; 2000. p. 102-31.

15. Huffman BA, Poltash ML, Hughey CA. Effect of polar protic and polar aprotic solvents on negative-ion electrospray ionization and chromatographic separation of small acidic molecules. Anal Chem 2012;84:9942-50.

16. Bello M, Olabanji I, Ibrahim A, Yekeen T, Oboh L. Nutraceuticals in leaves of Eucalyptus citriodora and Eucalyptus camandulensis. Int J Chem Environ Biol Sci 2013;3:2320-87.

17. Tepe B, Donmez E, Unlu M, Candan F, Daferera D, Vardar-Unlu G. Antimicrobial and antioxidative activities of the essential oils and methanol extracts of Salvia cryptantha (Montbret et Aucher ex Benth.) and Salvia multicaulis (Vahl). Food Chem 2004;84:519-25.

18. Lupo S, Tiscornia S, Bettucci L. Endophytic fungi from flowers, capsules and seeds of Eucalyptus globulus. Rev Iberoamericana Micologı 2001;181:38-41. 
19. Bonjar SGH. Evaluation of antibacterial properties of Iranian medicinal plants against Micrococcus luteus, Serratiamarcescens, Klebsiellapneunomiae and Bordella bronchoseptica. Asian J Plant Sci 2004;3:82-6.

20. Thenmozhi DC, Ramalakshmi V. Preliminary phytochemical screening and Antibacterial activity of Pergularia daemia. Int J Pharma Bio Sci 2011;2:162-6.

21. Cowan MM. Plant products as antimicrobial agents. Clin Microbiol Rev 1999;12:564-82.

22. Alexei YB, Joseph IS, Olga VF. Endogenous cardiotonic steroids: physiology, pharmacology and novel therapeutic targets. Pharmacol Rev 2009;61:9-38.

23. Varghese A, Gavani U, Abraham S, Parambi BGT, Sathyanarayanan, Jose A. Phytochemical screening and antimicrobial investigation of Typhaangustifolia Linn. Int J Chem Sci 2009;7:1905-10.
24. Banso A, Adeyemo S. Phytochemical screening and antimalarial assessment of Abutilon mauritianum, Bacopa monnifera and Datura stramonium. Biokemistri 2006;18:39-44.

25. Vladimir K, Ludmila M. Glycosides in medicine: the role of glycosidic residue in biological activity. Curr Med Chem 2009;8:1303-28.

26. Aiyelaagbe 00, Osamudiamen PM. Phytochemical screening for active compounds in Mangifera indica leaves from Ibadan, Oyo State. Plant Sci Res 2009;2:11-3.

\section{How to cite this article}

- $\quad$ Subramanian Abirami, Kannan Nishanthini, Mani Poonkothai Antimicrobial activity and phytochemical screening of the leaf extracts of Eucalyptus globulus. Int J Curr Pharm Res 2017;9(5):85-89. 